\title{
Postruminal synthesis modifies the odd- and branched- chain fatty acid profile from the duodenum to milk
}

\author{
B. Vlaeminck, ${ }^{*}$ R. Gervais, $†$ M. M. Rahman, ${ }^{*}$ F. Gadeyne, ${ }^{*}$ M. Gorniak,† M. Doreau, $\S$ and V. Fievez ${ }^{* 1}$ \\ *Laboratory for Animal Nutrition and Animal Product Quality, Faculty of Bioscience Engineering, Ghent University, Proefhoevestraat 10 , \\ 9090 Melle, Belgium \\ †Département des Sciences Animales, Université Laval, 2425 rue de l'Agriculture, Québec, Québec G1V 0A6, Canada \\ łInstitute of Animal Nutrition, Friedrich-Loeffler Institute, Federal Research Institute for Animal Health, Bundesallee 50, 38116 Brunswick, \\ Germany \\ §INRA/Vet Agro Sup, UMR1213 Herbivore Research Unit, 63122 Saint-Genès Champanelle, France
}

\section{ABSTRACT}

Milk odd- and branched-chain fatty acids (OBCFA) have been suggested as potential biomarkers for rumen function. The potential of milk OBCFA as a biomarker depends on whether their profile reflects the profile observed in the duodenum. The objective of this study was to evaluate whether the OBCFA profile in duodenum samples is reflected in plasma and milk. For this, 2 dairy cattle experiments were used. In experiment 1 , 4 Holstein cows fitted with rumen and proximal duodenum cannulas were used in a $4 \times 4$ Latin square design. The treatments consisted of 2 nitrogen levels (143 vs. $110 \mathrm{~g}$ of crude protein $/ \mathrm{kg}$ of dry matter for high and low $\mathrm{N}$, respectively) combined with either 1 of the 2 energy sources (i.e., starch from barley, corn, and wheat or fiber from soybean hulls and dehydrated beet pulp). In experiment 2, 4 Holstein cows fitted with rumen and proximal duodenum cannulas were used in a $3 \times 3$ Latin square design, with the treatments consisting of 3 diets: (1) RNB -, a diet with a crude protein content of $122 \mathrm{~g} / \mathrm{kg}$ of dry matter, predicted to provide protein digested in the small intestine according to the requirement of the animals, but with a shortage of rumen degradable protein; (2) RNB - to which $6 \mathrm{~g} / \mathrm{d}$ of niacin was added through inclusion in the mineral and vitamin premix, and (3) RNB - to which urea was added to balance rumen degradable $\mathrm{N}$ supply resulting in a $\mathrm{CP}$ content of $156 \mathrm{~g} / \mathrm{kg}$ of dry matter. In both experiments, samples of duodenal digesta, plasma, and milk were collected and analyzed for fatty acids. Additionally, lipids in plasma samples were separated in lipid classes and analyzed for fatty acids. The OBCFA profile in milk was enriched in 15:0, iso-17:0, anteiso-17:0, and cis-9-17:1 as compared with duodenal samples, and milk secretions even exceeded duodenal flows, which

Received December 8, 2014.

Accepted March 27, 2015.

${ }^{1}$ Corresponding author: Veerle.Fievez@UGent.be suggests occurrence of postruminal synthesis, such as de novo synthesis, desaturation, and elongation. The postruminal modification of the OBCFA profile might hamper the application of OBCFA as diagnostic tools of rumen function.

Key words: bovine, endogenous fatty acid synthesis, microbial fatty acids, elongation, blood lipids

\section{INTRODUCTION}

Milk odd- and branched-chain fatty acids (OBCFA) have been suggested as potential biomarkers of duodenal flow of microbial biomass (Cabrita et al., 2003; Vlaeminck et al., 2005) and molar proportions of VFA in the rumen (Fievez et al., 2012). Nevertheless, from other studies, the potential of these milk FA as biomarkers was questioned given the weak relationship between their duodenal flow and milk secretion (Dewhurst et al., 2007). The apparent recovery of duodenal FA in milk fat depends on various factors, including digestibility, FA metabolism (both synthesis and oxidation) in the cow's tissues, the cow's physiological status (positive vs. negative energy balance), blood lipid classes [NEFA, triacylglycerols (TAG), phospholipids (PL), or cholesterolesters $(\mathbf{C E})]$ in which FA are transported, and the duodenal FA flow, with higher transfer efficiencies at lower intestinal flows (Chilliard et al., 2000). Milk FA either are de novo synthesized or arise from plasma NEFA (mobilized from adipose tissue) or from TAGrich lipoproteins (chylomicrons and very low density lipoproteins). Fatty acids concentrated in CE and PL fractions of plasma are poorly transferred to milk fat because the mammary gland lipoprotein-lipase has a low affinity for these fractions (Annison et al., 1967; Shennan and Peaker, 2000). As a result, the profile of OBCFA in plasma and milk might be altered as compared with the duodenal profile. As adipose tissue is enriched in OBCFA of longer chain length (Craninx et al., 2008), differences in mobilization of body fat reserves also could contribute to the weak relationship 
between their duodenal flow and milk secretion. Furthermore, de novo synthesis in the mammary gland has been shown for 15:0 and 17:0 (Vlaeminck et al., 2006) as well as desaturation of 17:0 to cis-9-17:1 through the action of $\Delta^{9}$-desaturase (Fievez et al., 2003).

The aim of the present study was to gain additional insight in factors affecting the duodenum-milk relationship for OBCFA. Consequently, samples for the current study were obtained from 2 dairy cattle experiments initially designed to evaluate the effect of diet composition on efficiency of $\mathrm{N}$ utilization, and where large variation in duodenal flow of microbial protein (Fanchone et al., 2013; Aschemann et al., 2012), rumen proportions of VFA (Fanchone et al., 2013; Aschemann et al., 2012), and the rumen microbial population (Belanche et al., 2012) were measured. The dietary effect on both DMI, milk production and composition, and duodenal flow of microbial $\mathrm{N}$ were reported previously (Aschemann et al., 2012; Fanchone et al., 2013).

\section{MATERIALS AND METHODS}

The 2 experiments from which samples were obtained were explained in detail by Fanchone et al. (2013) and Aschemann et al. (2012). Brief descriptions of those experiments are given below. The proportions of ingredients used in the different treatments of both experiments and their nutritive values are presented in Table 1.

\section{Experiment 1 (Fanchone et al., 2013)}

Four Holstein cows fitted with rumen, proximal duodenum, and terminal ileum cannulas were used in a $4 \times 4$ Latin square design. At the beginning of the experiment the cows weighed on average $662 \pm 62 \mathrm{~kg}$ at $71 \pm 10$ DIM. The treatments consisted of 2 nitrogen levels (low and high) combined with either 1 of the 2 energy sources (high starch or high fiber). The high

Table 1. Dietary ingredients, chemical composition, and FA intake in experiment 1 and experiment $2^{1}$

\begin{tabular}{|c|c|c|c|c|c|c|c|}
\hline \multirow[b]{3}{*}{ Item } & \multicolumn{4}{|c|}{ Experiment $1^{2}$} & & & \\
\hline & \multicolumn{2}{|c|}{ Starch } & \multicolumn{2}{|c|}{ Fiber } & \multicolumn{3}{|c|}{ Experiment $2^{3}$} \\
\hline & $\underset{\mathrm{N}}{\text { High }}$ & $\begin{array}{c}\text { Low } \\
\mathrm{N}\end{array}$ & $\underset{\mathrm{N}}{\mathrm{High}}$ & $\begin{array}{c}\text { Low } \\
\mathrm{N}\end{array}$ & RNB- & RNB-NA & RNB0 \\
\hline \multicolumn{8}{|l|}{ Ingredient, $\mathrm{g} / \mathrm{kg}$ of $\mathrm{DM}$} \\
\hline Corn silage & 405 & 405 & 405 & 405 & 593 & 593 & 593 \\
\hline Hay & 100 & 100 & 100 & 100 & - & - & - \\
\hline Dehydrated alfalfa & 90 & 90 & 90 & 90 & - & - & - \\
\hline Molassed wheat straw & 52 & 63 & - & - & - & - & - \\
\hline Soybean hulls & - & - & 224 & 310 & - & - & - \\
\hline Dehydrated beet pulp & - & - & 90 & 90 & 61 & 61 & 58 \\
\hline Soybean meal & 108 & 36 & 86 & - & 82 & 82 & 82 \\
\hline Barley grain & 95 & 119 & - & - & 93 & 93 & 90 \\
\hline Wheat grain & 112 & 141 & - & - & 93 & 93 & 90 \\
\hline Corn grain & 36 & 46 & - & - & 77 & 77 & 74 \\
\hline Urea & 2 & - & 5 & 5 & - & - & 12 \\
\hline \multicolumn{8}{|c|}{ Chemical composition, $\mathrm{g} / \mathrm{kg}$ of DM } \\
\hline $\mathrm{OM}$ & 938 & 943 & 930 & 933 & 958 & 958 & 959 \\
\hline NDF & 361 & 362 & 471 & 507 & 343 & 343 & 342 \\
\hline $\mathrm{ADF}$ & 184 & 188 & 274 & 307 & 167 & 167 & 167 \\
\hline $\mathrm{CP}$ & 142 & 110 & 144 & 111 & 122 & 122 & 156 \\
\hline Rumen degradable protein & 98 & 74 & 97 & 76 & 98 & 97 & 134 \\
\hline Starch & 29 & 32 & 15 & 15 & $\mathrm{ND}^{4}$ & ND & ND \\
\hline \multicolumn{8}{|l|}{$\mathrm{FA}, \mathrm{g} / \mathrm{d}$} \\
\hline $16: 0$ & 66.9 & 70.4 & 56.5 & 52.8 & 71.2 & 70.0 & 70.1 \\
\hline $18: 0$ & 12.2 & 11.9 & 12.8 & 12.3 & 11.1 & 11.3 & 10.9 \\
\hline $18: 1$ & 83.9 & 89.0 & 82.0 & 77.7 & 110 & 109 & 110 \\
\hline $18: 2 \mathrm{n}-6$ & 189 & 198 & 154 & 140 & 247 & 245 & 242 \\
\hline $18: 3 n-3$ & 29.9 & 29.7 & 30.1 & 29.6 & 19.1 & 19.3 & 18.9 \\
\hline
\end{tabular}

${ }^{1}$ In experiments 1 and 2, 200 and $70 \mathrm{~g}$, respectively, of a vitamin-mineral supplement was fed daily per dairy cow with the concentrate.

${ }^{2}$ The high level of $\mathrm{N}$ met $110 \%$ of protein requirements of cows expressed in the French protein digestible in the intestine system, whereas the low level covered $80 \%$ of these requirements with a shortage in rumen-degradable N (Fanchone et al., 2013).

${ }^{3} \mathrm{RNB}=$ ruminal nitrogen balance, with $\mathrm{RNB}-=$ balanced diet in terms of ME and utilizable CP at the duodenum according to the average requirements of the dairy cows in experiment 2 , but with a shortage of rumen degradable protein $(\mathrm{RNB}=-0.41 \mathrm{~g}$ of $\mathrm{N} / \mathrm{MJ}$ of $\mathrm{ME}$ ); RNB-NA $=$ diet with the same composition as RNB - but to which $6 \mathrm{~g} / \mathrm{d}$ of niacin was added; RNB0 = diet with the same composition as RNB - but to which urea was added to balance rumen degradable $\mathrm{N}$ supply (RNB $=0.08 \mathrm{~g}$ of N/MJ of ME; Aschemann et al., 2012).

${ }^{4} \mathrm{ND}=$ not determined. 
nitrogen level met $110 \%$ of the cows requirements according to the French protein evaluation system (PDI, protein digestible in the intestine; INRA, 2007) with an adequate supply of rumen degradable $\mathrm{N}$, whereas the low $\mathrm{N}$ diets met $80 \%$ of the PDI requirements with a shortage of rumen degradable N. According to NRC (2001), high N diets met 106, 120, and $97 \%$ of the cow's requirements for microbial protein, rumen degradable protein, and rumen undegradable protein, whereas the low $\mathrm{N}$ diets met 95,93 , and $75 \%$ of microbial protein, rumen degradable protein, and rumen undegradable protein requirements, respectively. Soybean and urea were used as a source of $\mathrm{N}$. The forage proportion was the same for all 4 diets [corn silage, natural grass hay, and dehydrated alfalfa (Table 1)]. The diets were distributed twice daily at 0900 and $1700 \mathrm{~h}$. Each period lasted for $28 \mathrm{~d}, 21 \mathrm{~d}$ of adaptation, and the last $7 \mathrm{~d}$ for collection. Feed intake and refusal were weighed daily for individual cows on d 22 to 28. A 100-g sample of each ingredient of the diet was collected daily from $\mathrm{d}$ 24 to 28 for analysis of chemical composition. Duodenal nutrient flows were determined using $\mathrm{YbCl}_{3}$ as an external marker (Siddons et al., 1985). The Yb solution was infused continuously into the rumen via the ruminal cannula using a peristaltic pump from d 19 to 27 (i.e., $6 \mathrm{~d}$ before duodenal samplings). A daily quantity of $1.2 \mathrm{~g}$ of $\mathrm{Yb}$ dissolved in $2.4 \mathrm{~L}$ of water was infused for each cow. Sixteen duodenal samples of $250 \mathrm{~mL}$ were collected day and night from d 25 to 27 , providing representative samples of duodenal contents representing 1.5-h intervals over a day. These samples were pooled by animal within each period and frozen at $-20^{\circ} \mathrm{C}$. The cows were milked twice daily 0600 and $1600 \mathrm{~h}$, and milk yield was recorded. Milk samples were taken on d 24, 26, and 28. Morning and evening milk samples were pooled in a 60:40 ( $\mathrm{vol} / \mathrm{vol})$ and stored at $-18^{\circ} \mathrm{C}$ pending $\mathrm{FA}$ analysis. Blood was collected in an EDTA-containing tube on d 28 at $0830 \mathrm{~h}$ (preprandial) and $1130 \mathrm{~h}$ (postprandial) from a jugular vein. After collection, blood was centrifuged at $3,000 \times g$ for 15 min at $15^{\circ} \mathrm{C}$. The supernatant was separated and transferred into micro-tubes and stored at $-18^{\circ} \mathrm{C}$ pending FA analysis.

\section{Experiment 2 (Aschemann et al., 2012)}

Four Holstein cows fitted with rumen, proximal duodenum, and terminal ileum cannulas were used in a $3 \times 3$ Latin square design. Hence, in each period 2 cows were fed the same diet. Each period lasted for 6 wk: 3 wk of adaptation and 3 wk of sample collection. At the beginning of the experiment, the cows on average weighed $599 \pm 58 \mathrm{~kg}$ at $79 \pm 41 \mathrm{DIM}$. The treatments consisted of 3 diets, (1) RNB-, which was a balanced diet in terms of ME and utilizable $\mathrm{CP}$ at the duodenum according to the average requirements of the dairy cows in this experiment (GfE, 2001), but with a shortage of rumen degradable protein $(\mathrm{RNB}=-0.41 \mathrm{~g}$ of N/MJ of ME); (2) RNB-NA, which had the same composition as RNB- but to which $6 \mathrm{~g} / \mathrm{d}$ of niacin was added through inclusion in the mineral and vitamin premix; and (3) RNB0, which also had the same composition as RNB - but to which urea was added to balance rumen degradable $\mathrm{N}$ supply $(\mathrm{RNB}=0.08$ $\mathrm{g}$ of N/MJ of ME). Cows were fed at 0530 and $1500 \mathrm{~h}$ equal proportions of the daily amounts of corn silage and concentrate. To measure the duodenal digesta flow, chromium oxide $\left(19.8 \% \mathrm{Cr}_{2} \mathrm{O}_{3}, 79.1 \%\right.$ wheat flour, and $0.67 \% \mathrm{Al}_{2} \mathrm{SO}_{4}$ ) was used. The markers were introduced into the rumen in 2 portions of $50 \mathrm{~g}$ at 0515 and 1715 $\mathrm{h}$ beginning $10 \mathrm{~d}$ before the start of duodenal contents collection. One day before and during the collection period, $25 \mathrm{~g}$ of marker mix was administered every 6 $\mathrm{h}$ at $0545,1145,1745$, and $2345 \mathrm{~h}$. During the second sampling week, duodenal contents was collected over 5 consecutive days in 2-h intervals. At each sampling, 100-mL samples were taken through the duodenal cannula from each cow. These samples were pooled per day by animal and frozen at $-18^{\circ} \mathrm{C}$. Prior to statistical analysis, the average duodenal flow was calculated. The cows were milked twice daily at 0530 and $1530 \mathrm{~h}$, and milk yield was recorded. Milk samples were collected over $2 \mathrm{~d}$ of consecutive morning and evening milking in the first sampling week. Morning and evening milk samples were pooled in a $60: 40(\mathrm{vol} / \mathrm{vol})$ and stored at $-18^{\circ} \mathrm{C}$ for further analysis. Blood was collected in an EDTA-containing tube during $1 \mathrm{~d}$ of the third sampling week at $0530 \mathrm{~h}$ (preprandial) and at $0800 \mathrm{~h}$ (postprandial) from a jugular vein. After collection, blood was centrifuged at $3,000 \times g$ for $15 \mathrm{~min}$ at $15^{\circ} \mathrm{C}$. The supernatant was separated and transferred into microtubes and stored at $-18^{\circ} \mathrm{C}$ for further analysis.

\section{FA Analysis}

Fatty acid methyl esters were prepared from freezedried duodenal samples using a direct transesterification procedure as described by Vlaeminck et al. (2014). Milk fat was extracted according to Chouinard et al. (1997) and FAME prepared as described by Stefanov et al. (2010). Plasma lipids were extracted with methyl tert-butyl ether (MTBE) as described by Matyash et al. (2008). After extraction, MTBE was removed with a rotary evaporator. The lipid extract was divided into 2 aliquots. The FA composition was determined in a first aliquot of the lipid extract, using an alkaline followed by an acid methylation step (Vlaeminck et al., 2014) and the second aliquot was submitted to separation of 
blood plasma lipids into lipid classes using solid phase extraction columns (Burdge et al., 2000; Pinkart et al., 1998). Briefly, plasma lipid extracts were dissolved in chloroform $(1.0 \mathrm{~mL})$ and applied to an aminopropyl silica column (Pasteur pipette containing $100 \mathrm{mg}$ of aminopropyl silica gel) under gravity. Cholesterolesters and TAG were eluted with chloroform (1.0 and $0.5 \mathrm{~mL}$ ), combined, dried under $\mathrm{N}_{2}$, and dissolved in $1.0 \mathrm{~mL}$ of hexane. Nonesterified fatty acids were eluted with diethyl ether/acetic acid (100:2; 1.0 and $0.5 \mathrm{~mL})$ and PL with methanol/chloroform $(6: 1 ; 1 \mathrm{~mL})$ followed by $0.05 M$ sodium acetate in methanol/chloroform $(6: 1 ; 0.5 \mathrm{~mL})$. Cholesterol esters and TAG were further separated on a prepacked 100-mg aminopropyl column (Bond Elut-NH2, Varian Medical Systems Belgium, Diegem, Belgium). The fractions containing $\mathrm{CE}$ and TAG were loaded in $1 \mathrm{~mL}$ of hexane and $\mathrm{CE}$ were eluted with hexane $(1.0$ and $0.5 \mathrm{~mL})$. Triacylglycerols were eluted with hexane/chloroform/ethyl acetate (100:5:5; 1.0 and $0.5 \mathrm{~mL}$ ). Fatty acids in PL and CE were methylated using an alkaline followed by an acid methylation step (Vlaeminck et al., 2014). Fatty acids in the TAG fraction were methylated as described by Stefanov et al. (2010), whereas NEFA were methylated by an acid methylation step only (Vlaeminck et al., 2014).

Composition analysis of FA was carried out using a gas chromatograph (HP 6890A, Agilent Technologies, Diegem, Belgium) equipped with a 100-m CP-Sil88 capillary column (i.e., $0.25 \mu \mathrm{m}$, film thickness, $0.20 \mu \mathrm{m}$; Chrompack, Middelburg, the Netherlands) for milk and digesta samples and with a 75-m SP-2560 capillary column (i.d., $0.18 \mathrm{~mm}$, film thickness, $0.14 \mu \mathrm{m}$; Supelco Analytical, Bellefonte, PA) for plasma samples, and a flame ionization detector. A combination of 2 oven temperature programs was used in this study to achieve separation of most cis and trans 16:1, branched-chain FA, and 18:1 isomers (Kramer et al., 2008). For the first GC run, the temperature program was as follows: at the time of sample injection the column temperature was $70^{\circ} \mathrm{C}$ for $2 \mathrm{~min}$, then gradually increased at $15^{\circ} \mathrm{C} /$ min to $150^{\circ} \mathrm{C}$, followed by a second increase at $1^{\circ} \mathrm{C} /$ min to $165^{\circ} \mathrm{C}$ and maintained for $12 \mathrm{~min}$, followed by a third increase at $2^{\circ} \mathrm{C} / \mathrm{min}$ to $170^{\circ} \mathrm{C}$, maintained for $5 \mathrm{~min}$, and a final increase at $5^{\circ} \mathrm{C} / \mathrm{min}$ to $215^{\circ} \mathrm{C}$, and maintained for $20 \mathrm{~min}$. Injection volume was $1 \mu \mathrm{L}$ with a split ratio of 50:1. Inlet and detector temperatures were $250^{\circ} \mathrm{C}$ and $255^{\circ} \mathrm{C}$, respectively. The flow rate for hydrogen carrier gas was $1 \mathrm{~mL} / \mathrm{min}$. For the second GC run, the temperature program was as follows: at the time of sample injection the column temperature was $70^{\circ} \mathrm{C}$, then gradually increased at $50^{\circ} \mathrm{C} / \mathrm{min}$ to $175^{\circ} \mathrm{C}$ and maintained for $13 \mathrm{~min}$, followed by a final increase at $5^{\circ} \mathrm{C} / \mathrm{min}$ to $215^{\circ} \mathrm{C}$, and maintained for $20 \mathrm{~min}$. Injection volume was $0.5 \mu \mathrm{L}$ with a split ratio of 100:1.
The flow rate, inlet and detector temperatures were as for the first GC run. Most FA peaks were identified using quantitative mixtures of methyl ester standards (BR2 and BR3, Larodan Fine Chemicals, Malmö, Sweden). Also, aliquots of methylated samples were pooled and subsequently fractionated by thin layer chromatography on silica gel plates impregnated with silver nitrate according to Destaillats et al. (2007) with modifications, to confirm purity for peaks of interest in chromatograms and to eliminate peaks that were not FA (e.g., dimethyl acetals). An example chromatogram is provided as Supplemental Figure S1 (http://dx.doi. org/10.3168/jds.2014-9207).

\section{Statistical Analysis}

Data from experiment 1 were analyzed as a $4 \times 4$ Latin square using the MIXED procedure (SAS Institute Inc., Cary, NC). Proportions of OBCFA (g/100 g of FA) in duodenal content and milk were analyzed using the statistical model containing $\mathrm{N}$ level, energy source, and their interaction as fixed effect and cow and period as random effect. For proportions of OBCFA (g/100 $\mathrm{g}$ of FA) in plasma, data were additionally analyzed using the REPEATED statement, as variables were measured at different times of the day. This statistical model included the effects of $\mathrm{N}$ level, energy source, time, and their interactions. The effect of sampling time was evaluated as a repeated measure using the first-order autoregressive as covariance structure based on the Akaike's information criterion with cow within period as subject. The Kenward-Roger's method was used to calculate the degrees of freedom. For the evaluation of the effect of source (duodenum, plasma, milk) the model contained the fixed effect of $\mathrm{N}$ level, energy source and source, and their interactions, and cow and period as random effect.

The statistical model for evaluation of data from experiment 2 included the fixed effect of diet, and cow and period as random effect. When variables were measured at different times of the day (plasma samples), data were additionally analyzed using the REPEATED statement within the MIXED procedure. This statistical model included the effects of $\mathrm{N}$ level, energy source, time, and their interactions. The effect of sampling time was evaluated as a repeated measure using the first-order autoregressive as covariance structure based on the Akaike's information criterion with cow within period as subject. The Kenward-Roger's method was used to calculate the degrees of freedom. The effect of source (duodenum, plasma, and milk) was evaluated using the same model with the addition of the fixed effect of source and the interaction of source with $\mathrm{N}$ level, energy source, and their interaction. 
Principal component analysis using the PRINCOMP procedure in SAS was used to determine components which account for most of the total variation within OBCFA in duodenal, plasma TAG, and NEFA and milk samples. The principal component analysis was performed using data from experiment 1 and 2 simultaneously. Variables included were iso-15:0, anteiso-15:0, 15:0, iso-17:0, anteiso-17:0 and 17:0 (all expressed as $\mathrm{g} / 100 \mathrm{~g}$ of OBCFA). The principal component scores were calculated for each observation and submitted to statistical analysis as described above for experiment 1 and 2 .

\section{RESULTS}

\section{Duodenal Flow and Milk Secretion of OBCFA}

Dietary Effects. The effect of dietary treatment on duodenal flow and milk secretion of OBCFA is presented in Tables 2 and 3 for experiments 1 and 2, respectively. Dietary effects on proportion of OBCFA in duodenal content and milk are available as supplemental material (Supplemental Tables S1 and S2; http://dx.doi. org/10.3168/jds.2014-9207).

In experiment 1 , low levels of dietary $\mathrm{N}$ reduced duodenal flow and milk secretion of all OBCFA, except for cis-9-17:1 (Table 2). Starch rather than fiber as a carbohydrate source decreased duodenal flow as well as secretion in milk of iso and linear odd-chain FA. Carbohydrate source did not show a consistent effect on anteiso FA in duodenum and milk $(P<0.10)$, with starch reducing their secretion in milk, but not in the duodenum.

In experiment 2, dietary treatments induced only minor changes in duodenal flow and milk secretion of OBCFA (Table 3). When differences were observed, they were consistent with observations of experiment 1 , with lower levels of dietary $\mathrm{N}$ reducing duodenal flows and milk secretion of iso-14:0 and anteiso-15:0. Addition of niacin did not affect duodenal flow or milk secretion of OBCFA.

Source Effect (Duodenum vs. Milk). In experiments 1 and 2, duodenal flows of iso-14:0, iso-15:0, and anteiso-15:0 were greater $(P<0.01)$ compared with secretion in milk, whereas duodenal flow and milk secretion of iso-16:0 was similar $(P>0.10$; Tables 2 and 3). Duodenal flows and milk secretions of iso-17:0 and 17:0 did not differ $(P>0.10)$ in experiment 2 (Table 3), whereas milk secretions of iso-17:0 and 17:0 were greater $(P<0.001)$ compared with their duodenal flows in experiment 1 (Table 2). In both experiments, secretions in milk of anteiso-17:0, 15:0 and cis-9-17:1 were greater $(P<0.001)$ compared with their duodenal flows (Table 2 and 3 ). As a consequence, the ratio iso14:0 to iso-16:0, iso-15:0 to iso-17:0 and anteiso-15:0 to anteiso-17:0 were lower in milk compared with duodenal contents (Table 4).

\section{OBCFA Profile in Duodenum, Plasma Fractions, and Milk}

The profiles of OBCFA ( $\mathrm{g} / 100 \mathrm{~g}$ of OBCFA) in duodenum, milk, and plasma NEFA and TAG are presented in Table 5 . In both experiments, the proportions of 15:0, iso-17:0, anteiso-17:0, and cis-9-17:1 increased in milk compared with duodenal content, whereas iso14:0, iso-15:0, and anteiso-15:0 decreased. Plasma TAG and NEFA were enriched in FA with 17 carbon atoms, whereas iso-14:0, iso-15:0, and anteiso-15:0 decreased. No difference was observed in 15:0 between plasma TAG and duodenal content. Differences in the profile of OBCFA in duodenum, plasma NEFA, plasma TAG, and milk were further evaluated by means of principal component analysis (Figure 1). In both experiments, the first principal component (PC1) was mainly determined by a contrast between iso-15:0, anteiso-15:0, and iso-16:0, showing positive correlations with $\mathrm{PC} 1$, and iso-17:0, anteiso-17:0, and 17:0, which were negatively related to PC1. Duodenal samples had significantly higher scores for PC1 compared with milk and plasma NEFA and TAG (Table 5). Principal component 2 further separated milk samples from plasma NEFA and TAG.

Dietary effects on proportion of OBCFA in plasma lipids are available as supplemental material (Supplemental Tables S3, S4, S5, S6, and S7; http://dx.doi. org/10.3168/jds.2014-9207).

\section{DISCUSSION}

Milk OBCFA mainly originate from microbes leaving the rumen (Keeney et al., 1962) and were suggested as potential biomarkers of rumen function (Vlaeminck et al., 2006; Fievez et al., 2012). Obviously, the use of milk OBCFA as biomarker depends on whether the milk OBCFA profile is a reflection of the profile observed in the rumen or duodenum. What is novel in the present study is the parallel information on the profile of OB$\mathrm{CFA}$ in duodenal digesta, plasma lipid fractions, and milk, showing that the OBCFA profile in milk differed from the duodenal OBCFA profile and was more related to the profile in plasma TAG. The difference between milk and duodenum was due to a lower proportion in milk of branched-chain FA with 15 carbon atoms and an increase in 15:0, 17:0, and branched-chain FA with 17 carbon atoms. 
Table 2. Duodenal flow and milk secretion of odd- and branched-chain fatty acids (OBCFA; g/d) induced by feeding either a high-starch or high-fiber concentrate as energy source (E) at a low or high $\mathrm{N}$ level (N; experiment 1)

\begin{tabular}{|c|c|c|c|c|c|c|c|c|c|c|c|c|}
\hline \multirow[b]{2}{*}{ OBCFA } & \multirow[b]{2}{*}{ Source } & \multicolumn{2}{|c|}{$\mathrm{N}^{1}$} & \multirow[b]{2}{*}{ SEM } & \multicolumn{2}{|c|}{$\mathrm{E}$} & \multirow[b]{2}{*}{ SEM } & \multicolumn{5}{|c|}{$P$-value ${ }^{2}$} \\
\hline & & High & Low & & Fiber & Starch & & $\mathrm{S}$ & $\mathrm{N}$ & $\mathrm{E}$ & $\mathrm{S} \times \mathrm{N}$ & $\mathrm{S} \times \mathrm{E}$ \\
\hline iso-14:0 & $\begin{array}{l}\text { Duodenum } \\
\text { Milk }\end{array}$ & $\begin{array}{l}1.26 \\
1.01\end{array}$ & $\begin{array}{l}1.02 \\
0.90\end{array}$ & 0.113 & $\begin{array}{l}1.25 \\
1.14\end{array}$ & 1.03 & 0.114 & 0.001 & 0.002 & $<0.001$ & 0.181 & 0.161 \\
\hline iso- $15: 0$ & $\begin{array}{l}\text { Duodenum } \\
\text { Milk }\end{array}$ & $\begin{array}{l}3.63 \\
2.33\end{array}$ & $\begin{array}{l}2.64 \\
1.87\end{array}$ & 0.227 & $\begin{array}{l}1.41 \\
3.51 \\
2.58\end{array}$ & $\begin{array}{l}2.86 \\
1.62\end{array}$ & 0.288 & $<0.001$ & $<0.001$ & $<0.001$ & 0.006 & 0.026 \\
\hline anteiso-15:0 & $\begin{array}{l}\text { Duodenum } \\
\text { Milk }\end{array}$ & $\begin{array}{l}7.19 \\
4.54\end{array}$ & $\begin{array}{l}5.85 \\
3.88\end{array}$ & 0.450 & $\begin{array}{l}6.29 \\
4.65\end{array}$ & $\begin{array}{l}6.75 \\
3.76\end{array}$ & 0.450 & $<0.001$ & $<0.001$ & 0.404 & 0.204 & 0.017 \\
\hline 15:0 & $\begin{array}{l}\text { Duodenum } \\
\text { Milk }\end{array}$ & $\begin{array}{l}5.95 \\
8.15\end{array}$ & $\begin{array}{l}4.38 \\
7.23\end{array}$ & 0.605 & $\begin{array}{l}5.54 \\
8.16\end{array}$ & $\begin{array}{l}4.80 \\
7.22\end{array}$ & 0.609 & $<0.001$ & 0.003 & 0.041 & 0.376 & 0.771 \\
\hline iso-16:0 & $\begin{array}{l}\text { Duodenum } \\
\text { Milk }\end{array}$ & $\begin{array}{l}2.29 \\
2.34\end{array}$ & $\begin{array}{l}1.53 \\
1.78\end{array}$ & 0.280 & $\begin{array}{l}2.07 \\
2.40\end{array}$ & $\begin{array}{l}1.75 \\
1.72\end{array}$ & 0.282 & 0.283 & $<0.001$ & 0.002 & 0.448 & 0.184 \\
\hline iso- $17: 0$ & $\begin{array}{l}\text { Duodenum } \\
\text { Milk }\end{array}$ & $\begin{array}{l}1.55 \\
2.68\end{array}$ & $\begin{array}{l}1.21 \\
2.38\end{array}$ & 0.168 & $\begin{array}{l}1.41 \\
2.73\end{array}$ & $\begin{array}{l}1.36 \\
2.33\end{array}$ & 0.168 & $<0.001$ & 0.005 & 0.043 & 0.875 & 0.108 \\
\hline anteiso- $17: 0$ & $\begin{array}{l}\text { Duodenum } \\
\text { Milk }\end{array}$ & $\begin{array}{l}2.13 \\
4.17\end{array}$ & $\begin{array}{l}1.57 \\
3.44\end{array}$ & 0.312 & $\begin{array}{l}1.63 \\
4.01\end{array}$ & $\begin{array}{l}2.07 \\
3.59\end{array}$ & 0.312 & $<0.001$ & 0.007 & 0.988 & 0.711 & 0.061 \\
\hline $17: 0$ & $\begin{array}{l}\text { Duodenum } \\
\text { Milk }\end{array}$ & $\begin{array}{l}3.45 \\
3.99\end{array}$ & $\begin{array}{l}2.95 \\
3.64\end{array}$ & 0.232 & $\begin{array}{l}3.45 \\
4.30\end{array}$ & $\begin{array}{l}2.95 \\
3.34\end{array}$ & 0.233 & $<0.001$ & 0.011 & $<0.001$ & 0.642 & 0.135 \\
\hline cis-9 17:1 & $\begin{array}{l}\text { Duodenum } \\
\text { Milk }\end{array}$ & $\begin{array}{l}0.12 \\
1.69\end{array}$ & $\begin{array}{l}0.13 \\
1.56\end{array}$ & 0.093 & $\begin{array}{l}0.12 \\
1.69\end{array}$ & $\begin{array}{l}0.14 \\
1.57\end{array}$ & 0.093 & $<0.001$ & 0.384 & 0.438 & 0.283 & 0.283 \\
\hline
\end{tabular}

${ }^{1}$ The high level of $\mathrm{N}$ met $110 \%$ of protein requirements of cows expressed in the French protein digestible in the intestine system, whereas the low level covered $80 \%$ of these requirements with a shortage in rumen-degradable N (Fanchone et al., 2013).

${ }^{2} P_{\mathrm{E} \times \mathrm{N}}$ and $P_{\mathrm{S} \times \mathrm{E} \times \mathrm{N}}>0.1$. The source effect $(\mathrm{S})$ refers to the difference between duodenum and milk. 
Table 3. Duodenal flow and milk secretion of odd- and branched-chain fatty acids (OBCFA; g/d) induced by differences in rumen nitrogen balance and supplementation of niacin (experiment 2)

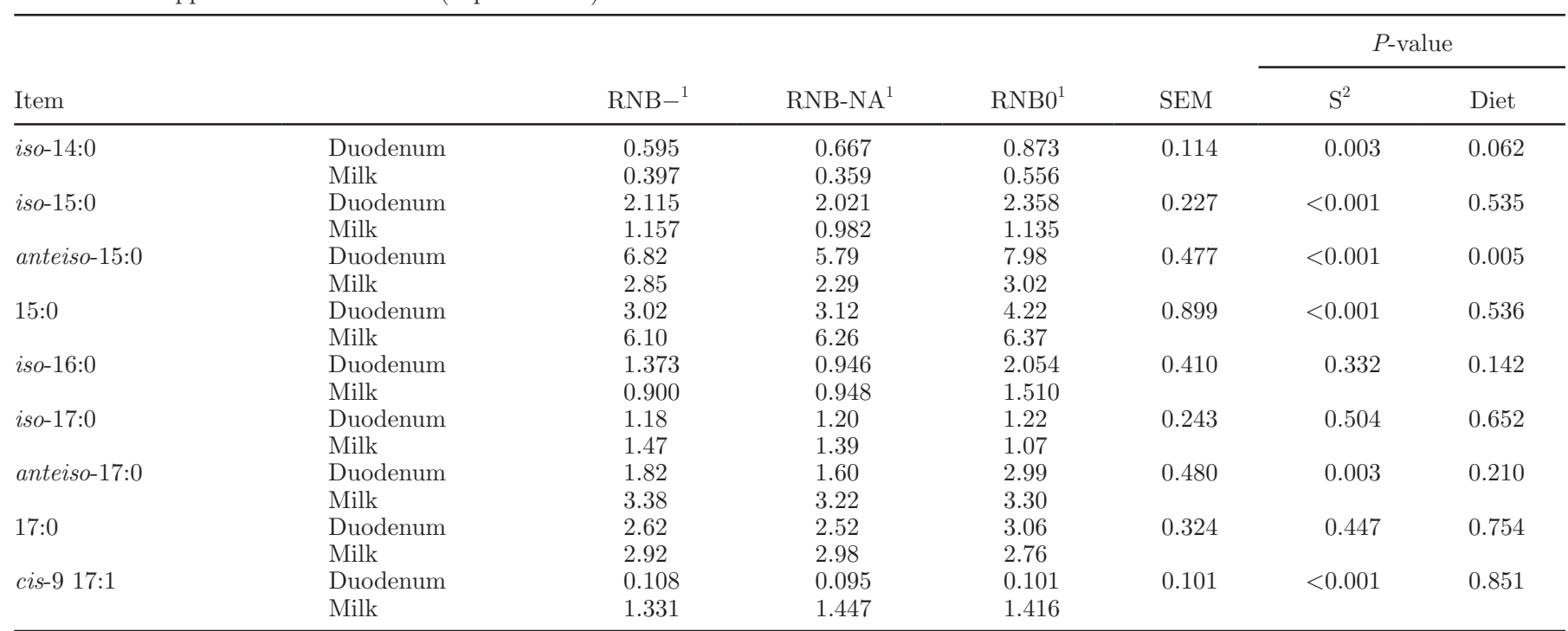

${ }^{1} \mathrm{RNB}=$ ruminal nitrogen balance, with $\mathrm{RNB}-=$ balanced diet in terms of $\mathrm{ME}$ and utilizable $\mathrm{CP}$ at the duodenum according to the average requirements of the dairy cows in experiment 2 , but with a shortage of rumen degradable protein $(\mathrm{RNB}=-0.41 \mathrm{~g}$ of $\mathrm{N} / \mathrm{MJ}$ of $\mathrm{ME}$ ); RNB-NA $=$ diet with the same composition as RNB - but to which $6 \mathrm{~g} / \mathrm{d}$ of niacin was added; RNB0 = diet with the same composition as RNB- but to which urea was added to balance rumen degradable $\mathrm{N}$ supply ( $\mathrm{RNB}=0.08 \mathrm{~g}$ of N/MJ of ME; Aschemann et al., 2012).

${ }^{2}$ The source effect $(\mathrm{S})$ refers to the difference between duodenum and milk.

\section{Linear Odd-Chain FA}

Earlier studies have shown that the straight-chain FA (15:0 and 17:0) can be synthesized de novo using propionyl-CoA instead of acetyl-CoA as primer for FA synthesis in the mammary gland (Scaife et al., 1978; Massart-Leën et al., 1983). Although the liver removes $\sim 94 \%$ of the net portal flux of propionate, splanchnic flux of propionate will increase when propionate supply is increased in the portal vein (Kristensen and Harmon, 2006), allowing some propionate to be used as primer for odd-chain FA synthesis. Ruminal infusion of propionate (Rigout et al., 2003; French et al., 2012) increases the proportion of odd-chain FA in milk fat, with a relatively smaller response in 17:0 than 15:0. The latter might relate to the desaturation of 17:0 in the mammary gland by the $\Delta^{9}$-desaturase, resulting in the formation of cis-9-17:1 (Fievez et al., 2003). Assuming duodenal 15:0 and 17:0 are completely secreted in milk, de novo synthesis of linear odd-chain FA accounts for, on average, $0.344 \pm 0.134(\mathrm{~g} / \mathrm{g}$, experiment 1$)$ and 0.374 $\pm 0.160(\mathrm{~g} / \mathrm{g}$, experiment 2$)$ of the linear odd-chain FA secreted in milk. Obviously, recovery of duodenal FA in milk is most likely less than 1 , due to incomplete duodenal absorption, oxidation, or incorporation in body tissues, which means that the contribution of de

Table 4. Ratios of odd- and branched-chain fatty acids (OBCFA) in duodenal contents, in blood plasma triacylglycerols (TAG) and NEFA, and in milk induced by feeding either a high-starch or high-fiber concentrate as an energy source at a low or high $\mathrm{N}$ level (experiment 1 ) or by differences in rumen nitrogen balance and supplementation of niacin (experiment 2)

\begin{tabular}{|c|c|c|c|c|c|c|c|}
\hline Item & $\begin{array}{l}\text { Experiment } \\
\text { (Exp.) }\end{array}$ & Duodenum & Milk & \multicolumn{2}{|c|}{ Plasma } & SEM & $P$-value \\
\hline iso-14:0/iso- $16: 0$ & Exp. 1 & $0.655^{\mathrm{a}}$ & $0.472^{\mathrm{b}}$ & - & $0.470^{\mathrm{b}}$ & 0.035 & $<0.001$ \\
\hline \multirow[t]{2}{*}{ iso-15:0/iso- $17: 0$} & Exp. 1 & $2.277^{\mathrm{c}}$ & $0.832^{\mathrm{b}}$ & $0.476^{\mathrm{a}}$ & $0.919^{\mathrm{b}}$ & 0.074 & $<0.001$ \\
\hline & Exp. 2 & $1.824^{\mathrm{b}}$ & $1.181^{\mathrm{ab}}$ & $0.773^{\mathrm{a}}$ & $0.777^{\mathrm{a}}$ & 0.199 & $<0.001$ \\
\hline anteiso- $15: 0 /$ anteiso- $17: 0$ & Exp. 1 & $3.975^{\mathrm{b}}$ & $1.104^{\mathrm{a}}$ & $0.817^{\mathrm{a}}$ & $1.372^{\mathrm{a}}$ & 0.018 & $<0.001$ \\
\hline $15: 0 /(17: 0+$ cis-9 17:1) & Exp. 2 & $1.208^{\mathrm{b}}$ & $1.426^{\mathrm{b}}$ & $0.588^{\mathrm{a}}$ & $0.557^{\mathrm{a}}$ & 0.076 & $<0.001$ \\
\hline
\end{tabular}

\footnotetext{
${ }^{\mathrm{a}-\mathrm{c}}$ Means within a row with different letters differ $(P<0.05)$.
} 
Table 5. Proportions of odd- and branched-chain fatty acids (OBCFA; g/100 g of OBCFA) and principal component scores (PC1 and PC2) in duodenal contents, in blood plasma triacylglycerols (TAG) and NEFA, and in milk induced by feeding either a high-starch or high-fiber concentrate as an energy source at a low or high $\mathrm{N}$ level (experiment 1 ) or by differences in rumen nitrogen balance and supplementation of niacin (experiment 2)

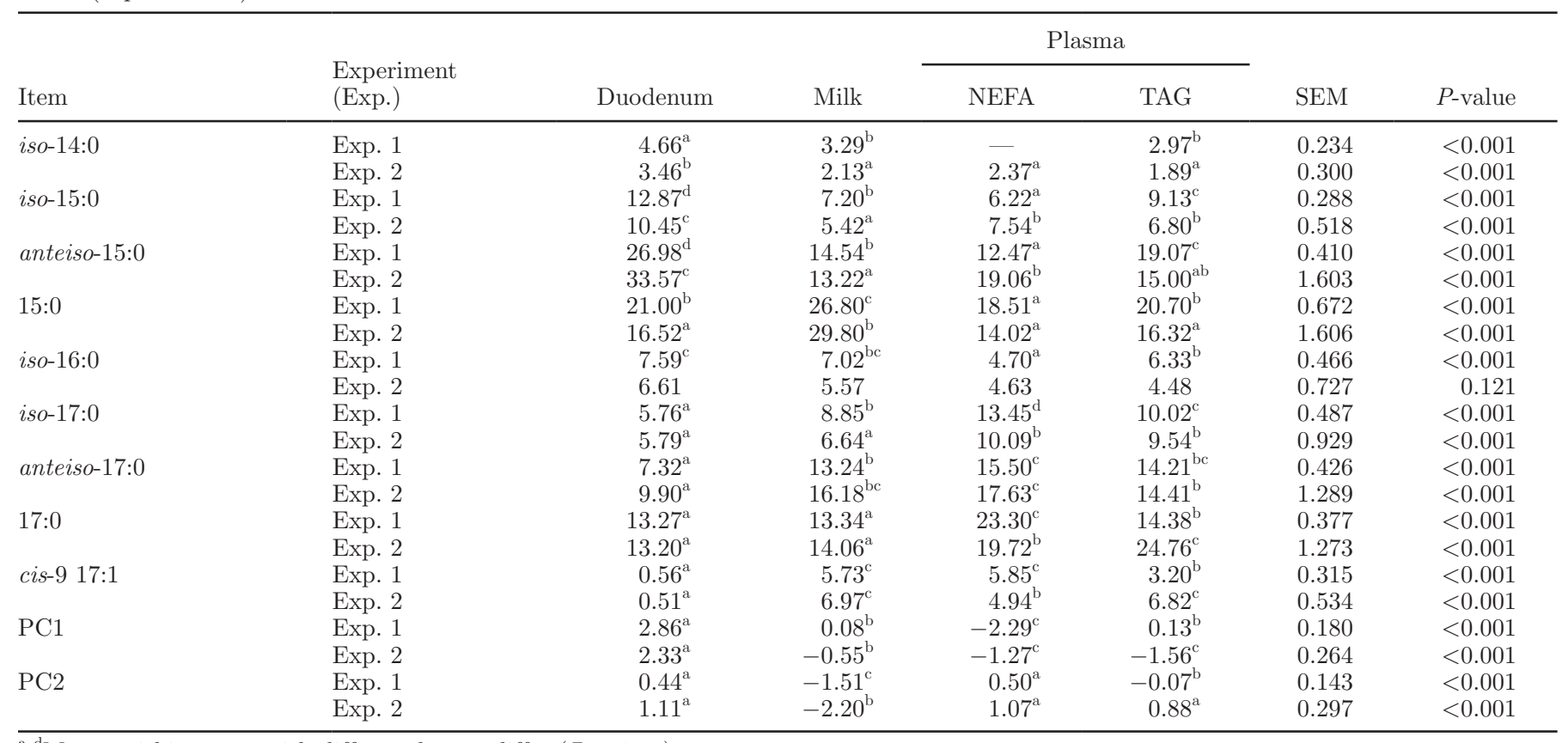

${ }^{\mathrm{a}-\mathrm{d}}$ Means within a row with different letters differ $(P<0.05)$.

novo synthesis is probably an underestimation. Hence, de novo synthesis of linear odd-chain FA contributes to a large extent to the secretion in milk of these FA.

\section{Branched-Chain FA}

The daily secretions in milk of iso-17:0 and anteiso-17:0 generally were greater as compared with their daily duodenal flow, except for iso-17:0 in experiment 2 , which was only numerically greater. Assuming duodenal iso-17:0 and anteiso-17:0 are completely secreted in milk, duodenal flow accounts for, on average, 0.660 $\pm 0.124(\mathrm{~g} / \mathrm{g}$, iso-17:0 experiment 1$), 0.486 \pm 0.190$ $(\mathrm{g} / \mathrm{g}$, anteiso- $17: 0$ experiment 1$)$, and $0.671 \pm 0.124$ (g/g, anteiso-17:0 experiment 2) of these FA secreted in milk. Obviously, recovery of duodenal FA in milk is most likely less than 1 , which means that the contribution is probably an overestimation. Similar results were observed previously (Vlaeminck et al., 2006; Dewhurst et al., 2007), but differences were then attributed to a potential overestimation of milk iso-17:0 and anteiso-17:0 due to possible co-elution with cis- or trans-16:1 isomers. The use of 2 temperature programs during GC analysis in the current experiments excluded co-elution problems (Kramer et al., 2008; Stefanov et al., 2010). Underestimated duodenal FA flows could also explain recovery values greater than 1 . Duodenal flow of OBCFA observed in the current experiments were in line with those previously reported (Dewhurst et al., 2007; Halmemies-Beauchet-Filleau et al., 2013). Recovery of total FA from feed to duodenum was 1.02 \pm 0.156 (mean $\pm \mathrm{SD}$ ) and was not affected by dietary treatments. This recovery is in the range of usually reported values (Schmidely et al., 2008). Combining these observations suggests that the greater secretion in milk of iso-17:0 and anteiso-17:0 compared with duodenal flows was not due to methodological errors or, in the worst case, could only explain a small part of this difference. Several alternative explanations are possible for the greater milk secretion compared with duodenal flow: (1) de novo synthesis of branched-chain FA from branched short-chain FA, (2) contribution of branched-chain FA released from the adipose tissue, and (3) chain elongation of branched-chain FA.

De novo synthesis of iso and anteiso FA in the mammary gland from isovaleryl-CoA or 2-methylbutyrylCoA as primers or when methylmalonyl-CoA instead of malonyl-CoA is used at the first step of chain elongation has been suggested to be negligible (Verbeke et al., 1959; Croom et al., 1981). In a recent study, ruminal infusion of isovalerate and 2-methylbutyrate increased their plasma concentrations but did not result in in- 


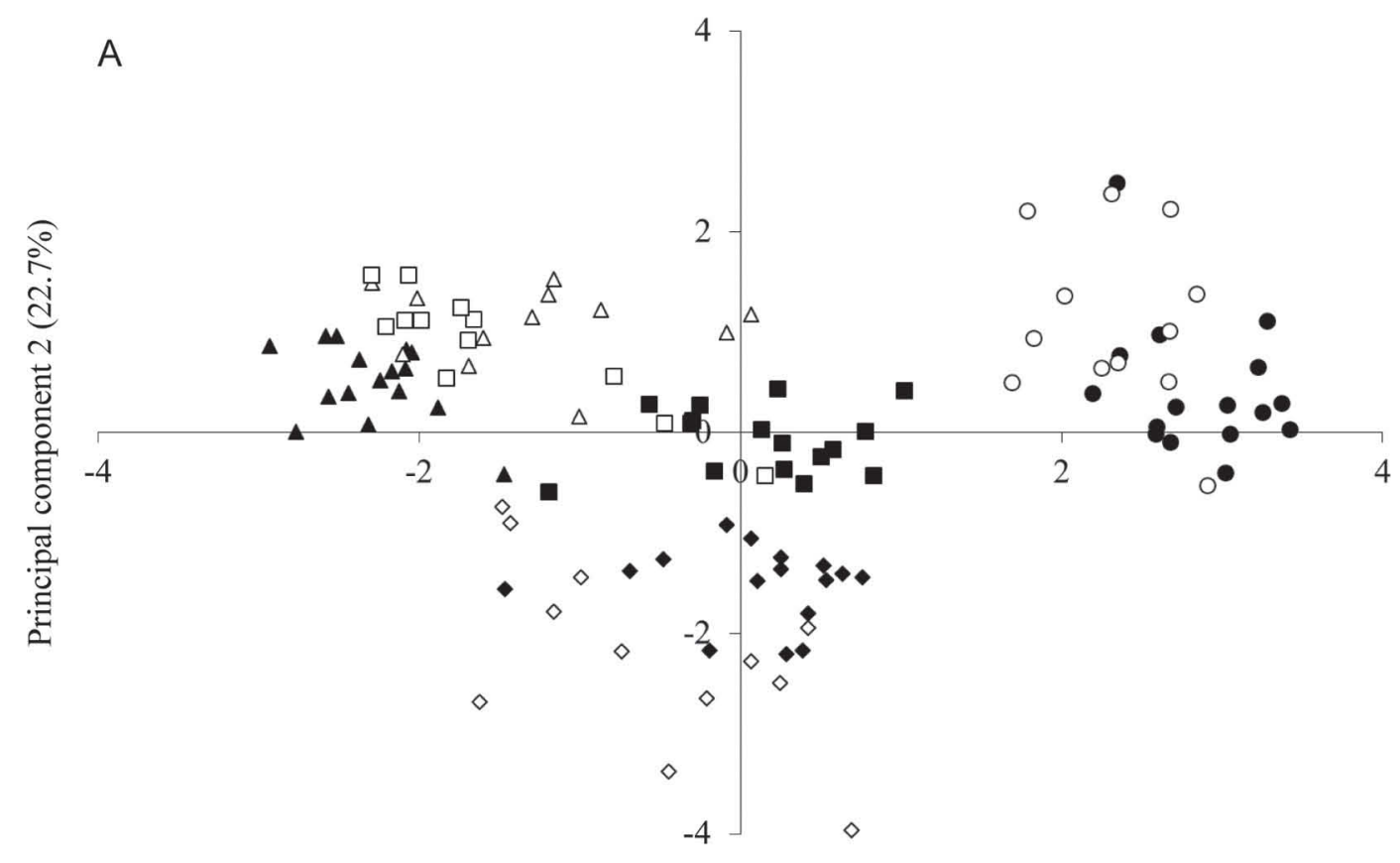

Principal component $1(47.4 \%)$

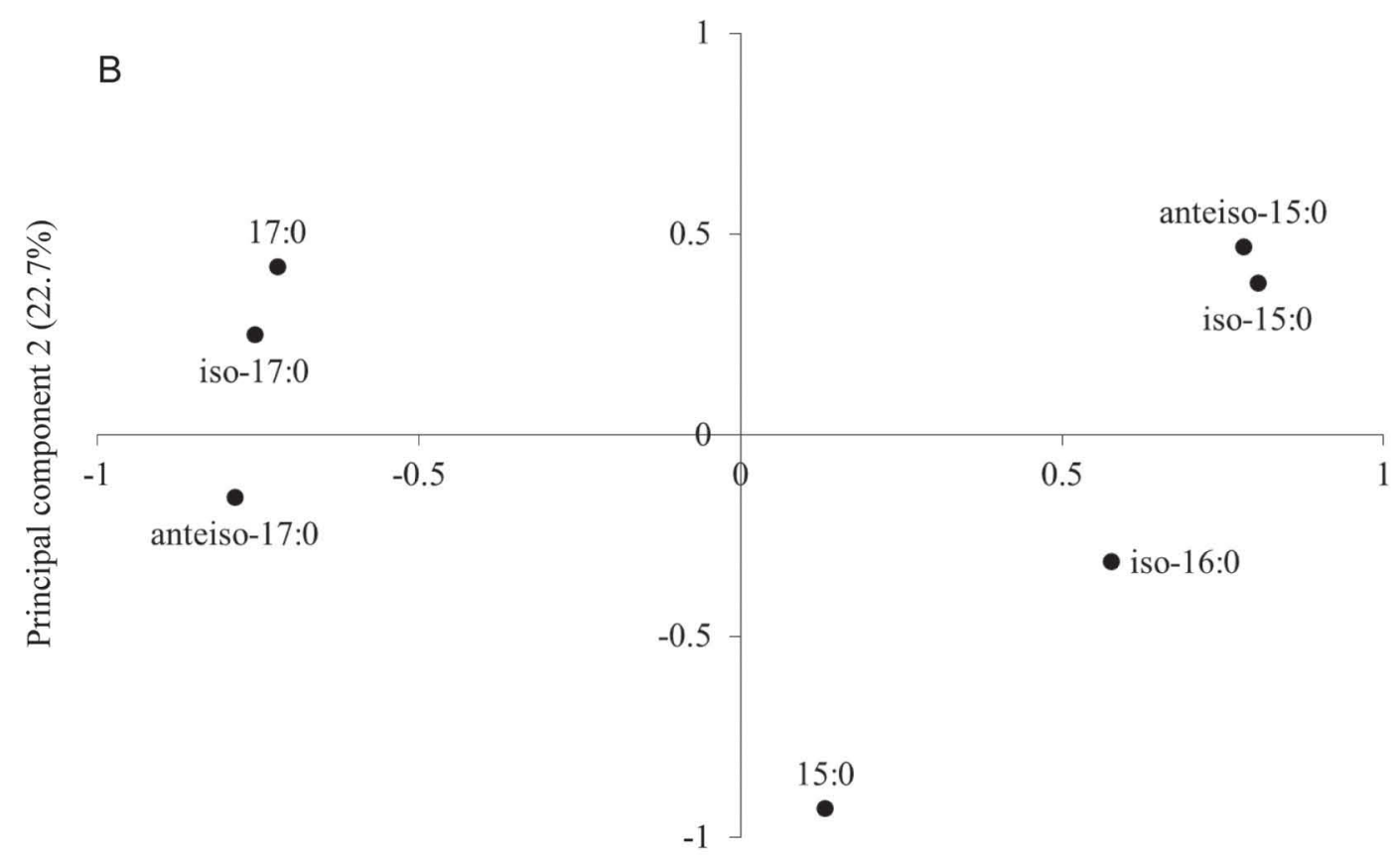

Principal component $1(47.4 \%)$

Figure 1. Principal component scores (A) and loadings (B) showing the separation of duodenal samples (circles) from milk samples (diamonds), plasma NEFA (triangles), and plasma TAG (squares) was mainly due to a contrast between, on the one hand, iso-15:0, anteiso-15:0, and iso-16:0; and iso-17:0, anteiso-17:0, and 17:0 on the other hand. Samples from experiment 1 and 2 are depicted as full and open symbols, respectively.

creased secretions of iso-17:0 or anteiso-17:0 in milk fat, suggesting limited use of the former for de novo synthesis of branched-chain FA (French et al., 2012).
Further, branched-chain FA mobilized from adipose tissue could contribute to the plasma pool available for secretion in milk (i.e., plasma NEFA). Indeed, Cra- 
ninx et al. (2008) suggested a nonnegligible release of branched-chain FA with a chain length of 17 carbon atoms during mobilization of the adipose tissue. Analysis of the OBCFA profile of NEFA in the current study showed this plasma fraction was enriched in branchedchain FA with a chain length of 17 carbon atoms as compared with duodenal samples (Table 5, Figure 1). However, cows in the current study were after peak lactation, suggesting contribution of iso-17:0 and anteiso-17:0 from adipose tissue mobilization was of limited importance. Proportions of iso-17:0 and anteiso-17:0 were also greater in plasma TAG than in duodenal contents, although FA in this lipid class predominantly originate from intestinal absorption (Demeyer and Doreau, 1999). Hence, endogenous chain elongation of iso-15:0 and anteiso-15:0 with 2 carbon atoms is a third possible explanation for the greater milk secretion of iso-17:0 and anteiso-17:0 compared with their duodenal flows. Fatty acid elongation with 2 carbon atoms to generate FA with chain lengths beyond 16 carbons is a very common process in various ruminant tissues, except for the mammary gland (Moore and Christie, 1981). Elongation of iso-15:0 and anteiso-15:0 to iso17:0 and anteiso-17:0 was observed before in the nematode Caenorhabditis elegans (Kniazeva et al., 2004) and in human intestinal cells (Ran-Ressler et al., 2009), with the enzyme ELOVL6 being responsible for this process (Kniazeva et al., 2004). Expression of ELOVL6 genes have been reported in bovine adipocyte cultures (Burns et al., 2012) and liver tissue (Loor et al., 2007). Fatty acid elongase activity also was demonstrated in bovine intestinal mucosa cells, although activity was substantially lower than in the liver and adipose tissue (Chang et al., 1992). The lower ratio iso-15:0 to iso17:0 and anteiso-15:0 to anteiso-17:0 in plasma TAG and milk as compared with duodenal samples might indicate elongation of iso-15:0 and anteiso-15:0 into iso17:0 and anteiso-17:0, respectively, takes place before uptake by the mammary gland (e.g., duodenal epithelial cells, liver). Obviously, changes in ratios depend on both the numerator and denominator. A change in the nominator due to, for example, a lesser digestibility, a preferential oxidation, or utilization by tissues compared with the denominator will equally result in a decreased ratio. However, the combined observation of (1) the greater milk secretion of iso-17:0 and anteiso-17:0 compared with their duodenal flows and (2) the lower ratio iso-15:0 to iso-17:0 and anteiso-15:0 to anteiso-17:0 in plasma TAG and milk as compared with duodenal samples suggest the occurrence of chain elongation of iso-15:0 and anteiso-15:0 with 2 carbon atoms.

\section{OBCFA as a Diagnostic Tool of Rumen Function}

The increase in branched-chain FA when a starch-rich concentrate was replaced with a fiber-rich concentrate were consistent with former observations (Vlaeminck et al., 2006), and most probably reflected the changes in relative abundance of specific bacterial populations in the rumen as observed in experiment 1 (Belanche et al., 2012). However, linear odd-chain FA also increased when a starch-rich concentrate was replaced with a fiber-rich one, which contradicts previously established relations (Vlaeminck et al., 2006; Fievez et al., 2012). Nevertheless, the greater rumen propionate proportions associated with the fiber-rich concentrate diet (Fanchone et al., 2013) possibly explain this observation.

Decreasing dietary $\mathrm{N}$ generally resulted in a lower proportion of OBCFA in duodenal content and milk. This is probably related to a shortage of $\mathrm{N}$ supply in the rumen, which may limit the growth of microbial biomass and, hence, the duodenal flow of microbial protein. This positive relation of dietary $\mathrm{N}$ with OBCFA, however, is in contrast with previous observations indicating a negative correlation of dietary $\mathrm{CP}$ content and proportions of milk OBCFA (Cabrita et al., 2003; Vlaeminck et al., 2006). These relations were established using a data set in which dietary $\mathrm{CP}$ content ranged from 140 to $175 \mathrm{~g} / \mathrm{kg}$ of DM (Cabrita et al., 2003) and 125 to $255 \mathrm{~g} / \mathrm{kg}$ of DM $(166 \pm 26 \mathrm{~g} / \mathrm{kg}$ of DM, mean \pm SD, Vlaeminck et al., 2006). Dietary CP content in the current experiments were at the lower end, which might indicate that the relation of dietary $\mathrm{CP}$ with OBCFA is not a linear but a quadratic relationship. Moreover, in both former data sets, dietary CP content was negatively related to dietary NDF content $(-0.455$, $P<0.001$, Cabrita et al., 2003; $-0.224, P=0.015$, Vlaeminck et al., 2006), which could have provoked some confounding effect.

The current data clearly showed the profile of OBCFA in milk differs from the profile in duodenal content, mainly due to de novo synthesis of linear odd-chain FA and elongation of branched-chain C15 FA to their C17 counterparts. This challenges, but not necessarily impairs, the potential of OBCFA as diagnostic tools of rumen function (Vlaeminck et al., 2006; Fievez et al., 2012). Knowledge on the factors affecting de novo synthesis of linear odd-chain FA and elongation of branched-chain C15 FA to their C17 counterparts is still limited and requires further research. When these processes occur in a predictable manner, corrections could be included in biomarker models (e.g., decreased de novo synthesis during milk fat depression). Recent reports show that mRNA expression encoding for ELOVL6 is affected by dietary energy intake (Loor et 
al., 2007; Ji et al., 2014), suggesting the extent of elongation might be related to dietary characteristics. In spite of these postruminal modifications of the OBCFA profile, dietary effects on OBCFA in duodenal content were generally reflected in milk. This suggest measurement of OBCFA in milk might provide information on OBCFA in duodenal content. However, differences induced by dietary treatments were generally smaller in milk as compared with differences observed in duodenal content, possibly due to postruminal modifications as described above.

\section{CONCLUSIONS}

For the first time, evidence has been generated of a postruminal 2-carbon elongation of branched-chain FA. Although postruminal synthesis and conversion changed the OBCFA profile from duodenum to milk, dietary effects were evident in both duodenal content and milk, although effects were generally smaller in milk as compared with duodenal content. The OBCFA profile in milk is most probably a reflection of the OBCFA profile available for digestion in the small intestine combined with modifications occurring from the duodenum to milk. As these postruminal modifications are likely, at least to some extent, related to ruminal processes, the OBCFA profile in milk might still provide information on rumen function.

\section{ACKNOWLEDGMENTS}

This research has been carried out with financial support from the Commission of the European Communities, FP7, KBB-2007-1 (Rednex). Bruno Vlaeminck has been supported by a postdoctoral grant of the Fund for Scientific Research-Flanders (Belgium). Part of this work was supported by the Industrial Research Chair program of Natural Sciences and Engineering Research Council of Canada (Ottawa, ON, Canada), with industry contributions from Dairy Farmers of Canada (Ottawa, ON, Canada), Novalait Inc. (Québec, QC, Canada), Valacta (Ste-Anne-de-Bellevue, QC, Canada), Fédération des Producteurs de Lait du Québec (Longueuil, QC, Canada), and Ministère de l'Agriculture, des Pêcheries et de l'Alimentation du Québec (Québec, QC, Canada). Additionally, research was supported by an international coordinated action of the Fund for Scientific Research-Flanders (FWO; Belgium).

\section{REFERENCES}

Annison, E. F., J. L. Linzell, S. Fazakerley, and B. W. Nichols. 1967. The oxidation and utilization of palmitate, stearate, oleate and acetate by the mammary gland of the fed goat in relation to their overall metabolism, and the role of plasma phospholipids and neutral lipids in milk-fat synthesis. Biochem. J. 102:637-647.

Aschemann, M., P. Lebzien, L. Huether, K.-H. Suedekum, and S. Daenicke. 2012. Effect of niacin supplementation on rumen fermentation characteristics and nutrient flow at the duodenum in lactating dairy cows fed a diet with a negative rumen nitrogen balance. Arch. Anim. Nutr. 66:303-318.

Belanche, A., M. Doreau, J. E. Edwards, J. M. Moorby, E. Pinloche, and C. J. Newbold. 2012. Shifts in the rumen microbiota due to the type of carbohydrate and level of protein ingested by dairy cattle are associated with changes in rumen fermentation. J. Nutr. 142:1684-1692.

Burdge, G. C., P. Wright, A. E. Jones, and S. A. Wootton. 2000. A method for separation of phosphatidylcholine, triacylglycerol, nonesterified fatty acids and cholesterol esters from plasma by solidphase extraction. Br. J. Nutr. 84:781-787.

Burns, T. A., S. K. Duckett, S. L. Pratt, and T. C. Jenkins. 2012. Supplemental palmitoleic (C16:1 cis-9) acid reduces lipogenesis and desaturation in bovine adipocyte cultures. J. Anim. Sci. 90:3433-3441.

Cabrita, A. R. J., A. J. M. Fonseca, R. J. Dewhurst, and E. Gomes. 2003. Nitrogen supplementation of corn silages. 2. Assessing rumen function using fatty acid profiles of bovine milk. J. Dairy Sci. 86:4020-4032.

Chang, J. H. P., D. K. Lunt, and S. B. Smith. 1992. Fatty acid composition and fatty acid elongase and stearoyl-CoA desaturase activities in tissues of steers fed high oleate sunflower seed. J. Nutr. 122:2074-2080.

Chilliard, Y., A. Ferlay, R. M. Mansbridge, and M. Doreau. 2000. Ruminant milk fat plasticity: Nutritional control of saturated, polyunsaturated, trans and conjugated fatty acids. Ann. Zootech. 49:181-205.

Chouinard, P. Y., V. Girard, and G. J. Brisson. 1997. Performance and profiles of milk fatty acids of cows fed full fat, heat-treated soybeans using various processing methods. J. Dairy Sci. 80:334-342.

Craninx, M., A. Steen, H. Van Laar, T. Van Nespen, J. Martín-Tereso, B. de Baets, and V. Fievez. 2008. Effect of lactation stage on the odd- and branched-chain milk fatty acids of dairy cattle under grazing and indoor conditions. J. Dairy Sci. 91:2662-2677.

Croom, W. J. Jr., D. E. Bauman, and C. L. Davis. 1981. Methylmalonic acid in low-fat milk syndrome. J. Dairy Sci. 64:649-654.

Demeyer, D., and M. Doreau. 1999. Targets and procedures for altering ruminant meat and milk lipids. Proc. Nutr. Soc. 58:593-607.

Destaillats, F., P.-A. Golay, F. Joffre, M. de Wispelaere, B. Hug, F. Giuffrida, L. Fauconnot, and F. Dionisi. 2007. Comparison of available analytical methods to measure trans-octadecenoic acid isomeric profile and content by gas-liquid chromatography in milk fat. J. Chromatogr. A 1145:222-228.

Dewhurst, R. J., J. M. Moorby, B. Vlaeminck, and V. Fievez. 2007. Apparent recovery of duodenal odd- and branched-chain fatty acids in milk of dairy cows. J. Dairy Sci. 90:1775-1780.

Fanchone, A., P. Nozière, J. Portelli, B. Duriot, V. Largeau, and M. Doreau. 2013. Effects of nitrogen underfeeding and energy source on nitrogen ruminal metabolism, digestion, and nitrogen partitioning in dairy cows. J. Anim. Sci. 91:895-906.

Fievez, V., E. Colman, J. M. Castro-Montoya, I. Stefanov, and B. Vlaeminck. 2012. Milk odd- and branched-chain fatty acids as biomarkers of rumen function-An update. Anim. Feed Sci. Technol. $172: 51-65$

Fievez, V., B. Vlaeminck, M. S. Dhanoa, and R. J. Dewhurst. 2003. Use of principal component analysis to investigate the origin of heptadecenoic and conjugated linoleic acids in milk. J. Dairy Sci. 86:4047-4053.

French, E. A., S. J. Bertics, and L. E. Armentano. 2012. Rumen and milk odd- and branched-chain fatty acid proportions are minimally influenced by ruminal volatile fatty acid infusions. J. Dairy Sci. 95:2015-2026.

GfE. 2001 Empfehlungen zur Energie-und Nährstoffversorgung der Milchkühe und Aufzuchtrinder. Ausschuss für Bedarfsnormen der Gesellschaft für Ernährungsphysiologie, DLG-Verlag, Frankfurt am Main, Germany. 
Halmemies-Beauchet-Filleau, A., P. Kairenius, S. Ahvenjärvi, L. K. Crosley, S. Muetzel, P. Huhtanen, A. Vanhatalo, V. Toivonen, R. J. Wallace, and K. J. Shingfield. 2013. Effect of forage conservation method on ruminal lipid metabolism and microbial ecology in lactating cows fed diets containing a 60:40 forage-to-concentrate ratio. J. Dairy Sci. 96:2428-2447.

INRA. 2007. Nutrition of Cattle, Sheep and Goats: Animal needsValues of feeds. Quae Ed., Paris, France.

Ji, P., J. K. Drackley, M. J. Khan, and J. J. Loor. 2014. Overfeeding energy upregulates peroxisome proliferator-activated receptor (PPAR) $\gamma$-controlled adipogenic and lypolytic gene networks but does not affect proinflammatory markers in visceral and subcutaneous adipose depots of Holstein cows. J. Dairy Sci. 97:3431-3440.

Keeney, M., I. Katz, and M. Allison. 1962. On probable origin of some milk fat acids in rumen microbial lipids. J. Am. Oil Chem. Soc. 39:198-201.

Kniazeva, M., Q. T. Crawford, M. Seiber, C.-Y. Wang, and M. Han. 2004. Monomethyl branched-chain fatty acids play an essential role in Caenorhabditis elegans development. PLoS Biol. 2:E257.

Kramer, J. K. G., M. Hernandez, C. Cruz-Hernandez, J. Kraft, and M. E. R. Dugan. 2008. Combining results of two GC separations partly achieves determination of all cis and trans 16:1, 18:1, 18:2 and 18:3 except CLA isomers of milk fat as demonstrated using Ag-ion SPE fractionation. Lipids 43:259-273.

Kristensen, N. B., and D. L. Harmon. 2006. Splanchnic metabolism of short-chain fatty acids in the ruminant. Pages 249-265 in Ruminant Physiology: Digestion, Metabolism and Impact of Nutrition on Gene Expression, Immunology and Stress. K. Sejrsen, T. Hvelplund, and M. O. Nielsen, ed. Wageningen Academic Publishers, Wageningen, the Netherlands.

Loor, J. J., R. E. Everts, M. Bionaz, H. M. Dann, D. E. Morin, R Oliveira, S. L. Rodriguez-Zas, J. K. Drackley, and H. A. Lewin. 2007. Nutrition-induced ketosis alters metabolic and signaling gene networks in liver of periparturient dairy cows. Physiol. Genomics 32:105-116.

Massart-Leën, A. M., E. Roets, G. Peeters, and R. Verbeke. 1983. Propionate for fatty acid synthesis by the mammary gland of the lactating goat. J. Dairy Sci. 66:1445-1454.

Matyash, V., G. Liebisch, T. V. Kurzchalia, A. Shevchenko, and D. Schwudke. 2008. Lipid extraction by methyl-tert-butyl ether for high-throughput lipidomics. J. Lipid Res. 49:1137-1146.

Moore, J. H., and W. W. Christie. 1981. Lipid metabolism in the mammary gland of ruminant animals. Pages 227-277 in Lipid Metabolism in Ruminant Animals. W. W. Christie, ed. Pergamon Press, Oxford, UK.
NRC. 2001. Nutrient Requirements of Dairy Cattle. 7th rev. ed. Natl. Acad. Sci., Washington, DC.

Pinkart, H. C., R. Devereux, and P. J. Chapman. 1998. Rapid separation of microbial lipids using solid phase extraction columns. J. Microbiol. Methods 34:9-15.

Ran-Ressler, R., R. Glahn, and J. Brenna. 2009. Branched chain fatty acids are elongated and incorporated into structural lipids in Caco2 human intestinal cells. Acta Paediatrica special issue: Abstracts of the 50th Annual Meeting of the European Society for Paediatric Research 9-12 October 2009, Hamburg, Germany. 90:94-95.

Rigout, S., C. Hurtaud, S. Lemosquet, A. Bach, and H. Rulquin. 2003. Lactational effect of propionic acid and duodenal glucose in cows. J. Dairy Sci. 86:243-253.

Scaife, J. R., K. W. J. Wahle, and G. A. Garton. 1978. Utilization of methylmalonate for the synthesis of branched-chain fatty acids by preparations of chicken liver and sheep adipose tissue. Biochem. J. 176:799-804.

Schmidely, P., F. Glasser, M. Doreau, and D. Sauvant. 2008. Digestion of fatty acids in ruminants: A meta-analysis of flows and variation factors. 1. Total fatty acids. Animal 2:677-690.

Shennan, D. B., and M. Peaker. 2000. Transport of milk constituents by the mammary gland. Physiol. Rev. 80:925-951.

Siddons, R. C., J. Paradine, D. E. Beever, and P. R. Cornell. 1985. Ytterbium acetate as a particulate-phase digesta-flow marker. Br. J. Nutr. 54:509-519.

Stefanov, I., V. Baeten, O. Abbas, E. Colman, B. Vlaeminck, B. De Baets, and V. Fievez. 2010. Analysis of milk odd- and branchedchain fatty acids using Fourier Transform (FT)-Raman spectroscopy. J. Agric. Food Chem. 58:10804-10811.

Verbeke, R., M. Lauryssens, G. Peeters, and A. T. James. 1959. Incorporation of DL- $[1-14 \mathrm{C}]$ leucine and $[1-14 \mathrm{C}]$ isovaleric acid into milk constituents by the perfused cow's udder. Biochem. J. 73:24-29.

Vlaeminck, B., T. Braeckman, and V. Fievez. 2014. Rumen metabolism of 22:6n-3 in vitro is dependent on its concentration and inoculum size, but less dependent on substrate carbohydrate composition. Lipids 49:517-525.

Vlaeminck, B., C. Dufour, A. M. van Vuuren, A. R. J. Cabrita, R J. Dewhurst, D. Demeyer, and V. Fievez. 2005. Use of odd and branched-chain fatty acids in rumen contents and milk as a potential microbial marker. J. Dairy Sci. 88:1031-1042.

Vlaeminck, B., V. Fievez, A. R. J. Cabrita, A. J. M. Fonseca, and R. J. Dewhurst. 2006. Factors affecting odd- and branched-chain fatty acids in milk: A review. Anim. Feed Sci. Technol. 131:389-417. 